\title{
Value of serum C-reactive protein measurement in the investigation of fever in systemic lupus erythematosus
}

\author{
G. J. BECKER, ${ }^{1}$ M. WALDBURGER, ${ }^{2}$ G. R. V. HUGHES, ${ }^{2}$ AND \\ M. B. PEPYS ${ }^{1}$
}

From the ${ }^{1}$ Immunological Medicine Unit and the ${ }^{2}$ Rheumatology Unit, Department of Medicine, Royal Postgraduate Medical School, London

SUMMARY The concentration of C-reactive protein (CRP) in the sera of patients with systemic lupus erythematosus (SLE) was higher when the disease was active than when it was inactive, but was only markedly raised in patients suffering from identifiable microbial infection. CRP levels greater than $60 \mathrm{mg} / \mathrm{l}$ suggest the presence of intercurrent infection and may therefore be a valuable aid to the differential diagnosis of pyrexia in SLE.

Pyrexia in systemic lupus erythematosus SLE is a common and important clinical problem (Hughes, 1977), particularly in patients who are being treated with anti-inflammatory or immunosuppressive drugs. The differential diagnosis, which usually lies between intercurrent infection and simple exacerbation of the underlying disease, may often be difficult to resolve rapidly. The erythrocyte sedimentation rate (ESR) is not a good index of disease activity in SLE (Hughes, 1977). Although the ESR does tend to rise with intercurrent infection, this does not differentiate it from active SLE alone with high ESR. Furthermore plasma viscosity and to an even greater extent ESR are determined by many variables and respond rather slowly and very variably to alterations in disease activity and other stimuli (Pepys, 1979a).

\section{Patients and methods}

Forty-one patients fulfilling the American Rheumatology Association criteria for the classification of SLE were studied longitudinally with a total of 214 sera collected over the 24-month period prior to June 1978. Their disease was regarded as active if vasculitis, serositis, arthritis, cerebral lupus, or severe glomerulonephritis was present. Infection was diagnosed only when clinical evidence was supported by microbiological studies. Patients with mild

Accepted for publication 29 January 1979

Correspondence to Dr M. B. Pepys, Immunological Medicine Unit, Department of Medicine, Royal Postgraduate polyarthralgia or rash as well as those with no symptoms were included in the 'inactive' group.

Serum samples were stored at $-20^{\circ}$ until tested. CRP levels were measured by a monospecific sheep antiserum in electroimmuno assay (Kindmark, 1969) in the presence of EDTA, with the isolated pure protein (Pepys et al., 1977a) as the standard. The lower limit of sensitivity was $1 \mathrm{mg} / 1$, and the coefficient of variation in replicate assays was less than $10 \%$. Results can be obtained within 8 hours of venepuncture. The highest CRP level found in each patient during phases of infection, activity, or inactivity were compared. Significance of differences between the groups was assessed by Wilcoxon's rank sum test.

\section{Results}

During the 2-year period 9 of the 41 patients suffered from proved infections (Table 1);25 patients

\section{Table 1 Nature of infective episodes}

\begin{tabular}{|c|c|}
\hline Infection & Number of patients \\
\hline $\begin{array}{l}\text { Staphylococcus aureus cellulitis } \\
\text { Streptococcus pneumoniae septicaemia } \\
\text { Streptococcus pneumoniae pneumonia } \\
\text { Streptococcus group D septicaemia } \\
\text { Candida albicans infection of mouth and } \\
\text { vagina } \\
\text { Escherichia coli urinary tract infection } \\
\text { Cytomegalovirus pulmonary infection } \\
\text { Proteus mirabilis urinary tract } \\
\text { infection }\end{array}$ & $\begin{array}{l}3 \\
2 \\
1 \\
1 \\
1 \\
1\end{array}$ \\
\hline
\end{tabular}


had periods of disease activity and 28 patients had periods with inactive disease. The maximum CRP levels reached during these different phases are shown in Fig. 1 and Table 2. The CRP levels in infected patients with SLE were significantly higher than in patients with active SLE alone $(P<0 \cdot 01)$. The CRP levels in patients with active SLE were higher that in the inactive group $(\mathrm{P}<0 \cdot 01)$.

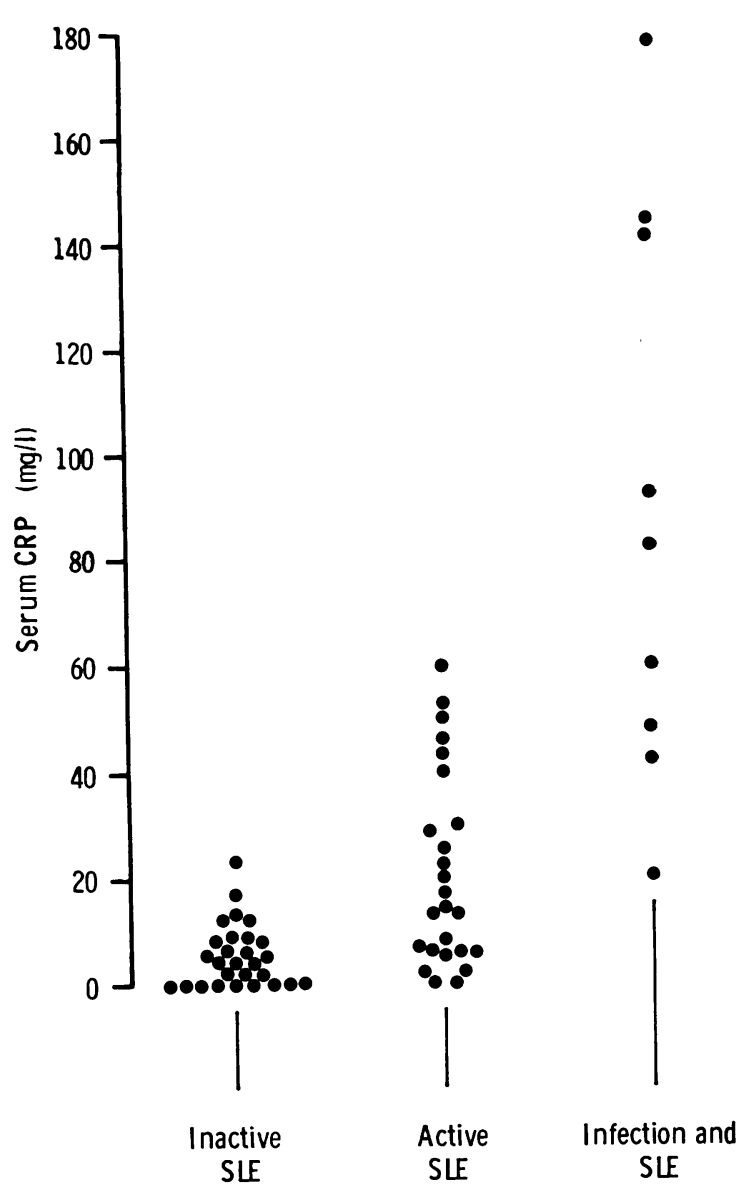

Fig. 1 Maximum serum CRP levels in patients with $S L E$

Table 2 Maximum serum CRP levels

\begin{tabular}{|c|c|c|c|c|}
\hline \multirow{2}{*}{$\begin{array}{l}\text { Clinical } \\
\text { category }\end{array}$} & \multirow{2}{*}{$\begin{array}{l}\text { No. of } \\
\text { patients }\end{array}$} & \multicolumn{3}{|c|}{ Serum CRP level $(m g / l)$} \\
\hline & & Median & $\begin{array}{l}\text { Interquartile } \\
\text { range }\end{array}$ & Range \\
\hline $\begin{array}{l}\text { Inactive SLE } \\
\text { Active SLE } \\
\text { Infection and } \\
\quad \text { SLE }\end{array}$ & $\begin{array}{r}28 \\
25 \\
9\end{array}$ & $\begin{array}{r}4 \\
14 \\
\\
82\end{array}$ & $\begin{array}{c}0-8 \\
6-30 \\
48-141\end{array}$ & $\begin{array}{r}0-23 \\
0-60 \\
20-177\end{array}$ \\
\hline
\end{tabular}

\section{Discussion}

CRP is a major acute phase reactant, the serum level rising from normal values of less than $1 \mathrm{mg} / 1$ to as much as $400 \mathrm{mg} / 1$ within 1 or 2 days following many forms of actue tissue damage or inflammation (Kindmark, 1976; Pepys et al., 1978a). In some chronic inflammatory conditions and with malignant neoplasia CRP levels remain raised and may reflect disease activity (Claus et al., 1976; Pepys et al., 1978a). Thus, although elevation of CRP is a non-specific response, its assay is clinically useful in monitoring the activity of rheumatoid arthritis (Amos et al., 1977), rheumatic fever (Stollerman et al., 1953) and Crohn's disease (Pepys et al., 1977b). In contrast we have observed that in ulcerative colitis (Pepys et al., 1977b) and SLE (Pepys et al., 1978a) CRP is only moderately raised even in severe exacerbations and may correlate poorly with disease activity. Honig et al. (1977), using a semiquantitative precipitation assay to study CRP levels in SLE, found raised levels in the sera of patients who were suffering from microbial infection.

With a more sensitive and precise technique we here confirm that in SLE marked elevation of CRP is largely confined to patients with identifiable microbial infections. We also show that CRP levels tend to be higher in active than in inactive lupus, although in the absence of infection the value did not exceed $60 \mathrm{mg} / 1$ even in patients with florid disease activity. Estimation of serum CRP may therefore be valuable in management of patients with SLE, up to $80 \%$ of whom are febrile at some time in their illness (Estes and Christian, 1971; Hughes, 1977). The modest increase of CRP even in patients with very active lupus is surprising in view of the extensive tissue damage and the frequent presence of circulating immune complexes. Such complexes are known to stimulate CRP production in the rabbit (Hokama et al., 1960; Kushner and Kaplan, 1964). Mechanisms for the lack of high CRP levels in SLE which we are currently studying include reduced production, enhanced consumption, and complexing of CRP in the serum.

One intriguing possibility is that there might be individual genetic differences in the capacity to respond to some stimuli with CRP production. This has recently been observed in inbred strains of mice both for CRP (Siboo and Kulisek, 1978), which is only a trace protein in this species (Siboo and Kulisek, 1978; Pepys 1979b), and for SAP (serum amyloid P-component) (Skinner and Cohen, 1976; Pepys et al., 1979), which is closely related to CRP (Osmand et al., 1977; Pepys et al., 1977c, 1978b), and is a major murine acute phase plasma protein (Pepys et al., 1979). Human CRP interacts with 
complement (Kaplan and Volanakis, 1974; Siegal et al., 1975) and phagocytic cells (Kindmark, 1971; Mortensen et al., 1976). Hereditary effects on production of these proteins might therefore be of pathogenetic significance in inflammatory disease and possibly play a part in determining the pattern of diseases evoked in different individuals by the same agent.

Our present observations might, however, be secondary to the well recognised immunological abnormalities which characterise SLE. Elucidation of this issue must wait for further information on the control mechanisms for CRP production and the role of CRP in inflammation in vivo. In any event at the purely clinical level the measurement of serum CRP is a valuable aid to the detection of intercurrent microbial infection in patients with SLE.

We thank the National Kidney Research Foundation, the Arthritis and Rheumatism Council, the Wellcome Trust, and Winthrop Travelling Fellowship (RACP) (G.J.B.) for support.

\section{References}

Amos, R. S., Constable, T. J., Crockson, R. A., Crockson, A. P., and McConkey, B. (1977). Rheumatoid arthritis: relation of serum C-reactive protein and erythrocyte sedimentation rates to radiographic changes. British Medical Journal, 1, 195-197.

Claus, D. R., Osmand, A. P., and Gewurz, H. (1976). Radioimmunoassay of human $\mathrm{C}$-reactive protein and levels in normal sera. Journal of Laboratory and Clinical Medicine, 87, 120-128.

Estes, D., and Christian, C. L. (1971). The natural history of systemic lupus erythematosus by prospective analysis. Medicine, 50, 85-95.

Hokama, Y., Coleman, M. K., and Riley, R. F. (1960). Cx-reactive protein response in rabbits during immunisation with foreign proteins. Journal of Immunology, 85, 72-77.

Honig, S., Gorevic, P., and Weissmann, G. (1977). C-reactive protein in systemic lupus erythematosus. Arthritis and Rheumatism, 20, 1065-1070.

Hughes, G. R. V. (1977). Connective Tissue Diseases. Blackwell Scientific Publications: Oxford.

Kaplan, M. H., and Volanakis, J. E. (1974). Interaction of C-reactive protein complexes with the complement system. I. Consumption of human complement associated with the reaction of $\mathrm{C}$-reactive protein with pneumococcal C-polysaccharide and with the choline phosphatides, lecithin and sphingomyelin. Journal of Immunology, 112, 2135-2147.

Kindmark, C. O. (1969). Quantitative measurement of C-reactive protein in serum. Clinica Chimica Acta, 26, 95-98.

Kindmark, C. O. (1971). Stimulating effect of C-reactive protein on phagocytosis of various species of pathogenic bacteria. Clinical and Experimental Immunology, 8, 941-948.

Kindmark, C. O. (1976). Sequential changes in plasma proteins in various aucte diseases. In Plasma Protein Turnover, pp. 395-402. Edited by R. Bianchi, B. Mariani, and A. S. MacFarlane. Macmillan: London.
Kushner, I., and Kaplan, M. H. (1964). Studies of acute phase protein. III. Elicitation of Cx-reactive protein in relation to immune elimination of antigen and appearance of circulating antigen-antibody complexes. Journal of Immunology, 92, 55-60.

Mortensen, R. F., Osmand, A. P., Lint, T. F., and Gewurz, H. (1976). Interaction of C-reactive protein with lymphocytes and monocytes: complement-dependent adherence and phagocytosis. Journal of Immunology, 117, 774-781.

Osmand, A. P., Friedenson, B., Gewurz, H., Painter, R. H., Hofmann, T., and Shelton, E. (1977). Characterisation of C-reactive protein and the complement subcomponent Clt as homologous protein displaying cyclic pentameric symmetry (pentraxins). Proceedings of the National Academy of Sciences of the USA, 74, 739-743.

Pepys, M. B. (1979a). Acute phase phenomena. The Science and Practice of Clinical Medicine. Rheumatology and Immunology. Edited by A. S. Cohen. Grune and Stratton: New York. In press.

Pepys, M. B. (1979b). Isolation of serum amyloid P-component (protein SAP) in the mouse. Immunology, in press.

Pepys, M. B., Dash, A. C., and Ashley, J. (1977a). Isolation of C-reactive protein by affinity chromatography. Clinical and Experimental Immunology, 30, 32-37.

Pepys, M. B., Drugnet, M., Klass, H. J., Dash, A. C., Mirjah, D. D., and Petrie, A. (1977b). Immunological studies in inflammatory bowel disease. Immunology of the Gut, Ciba Foundation Symposium 46 (new series), pp. 283-304. Edited by J. Knight, Elsevier/Excerpta Medica/North-Holland: Amsterdam.

Pepys, M. B., Dash, A. C., Munn, E. A., Feinstein, A., Skinner, M., Cohen, A. S., Gewurz, H., Osmand, A. P., and Painter, R. H. (1977c). Isolation of amyloid Pcomponent (protein AP) from normal serum as a calciumdependent binding protein. Lancet, 1, 1029-1031.

Pepys, M. B., Dash, A. C., Markham, R. E., Thomas, H. C., Williams, B. D., and Petrie, A. (1978a). Comparative clinical study of protein SAP (amyloid-P component) and C-reactive protein in serum. Clinical and Experimental Immunology, 32, 119-124.

Pepys, M. B., Dash, A. C., Fletcher, T. C., Richardson, N., Munn, E. A., and Feinstein, A. (1978b). Analogues in other mammals and in fish of human plasma proteins $\mathrm{C}$-reactive protein and amyloid P-component. Nature, 273, 168-170.

Pepys, M. B., Baltz, M., Gomer, K., Davies, A. J. S., and Doenhoff, M. (1979). Serum amyloid P-component is an acute phase reactant in the mouse. Nature, 278, 259-261.

Siboo, R., and Kulisek, E. (1978). A fluorescent immunoassay for quantification of C-reactive protein. Journal of Immunological Methods, 23, 59-67.

Siegel, J., Osmand, A. P., Wilson, M. F., and Gewurz, H. (1975). Interactions of C-reactive protein with the complement system. II. C-reactive protein-mediated consumption of complement by poly-L-lysine polymers and other polycations. Journal of Experimental Medicine, 142, 709-721.

Skinner, M., and Cohen, A. S. (1976). Aspects of the amyloid P-component. In Amyloidosis, pp. 339-352. Edited by O. Wegelius and A. Pasternack, Academic Press: London.

Stollerman, G. M., Glick, S., Patel, D. J., Hirschfeld, I., and Rusoff, J. H. (1953). Determination of C-reactive protein in serum as a guide to the treatment and management of rheumatic fever. American Journal of Medicine, 15, 645-655. 